\title{
Open
}

\section{Insurance Convergence and Post-crisis Dynamics in Central and Eastern Europe}

\author{
Martin Ertl \\ UNIQA Insurance Group AG, UNIQA Capital Markets GmbH, Untere Donaustraße 21, Vienna 1029, Austria. \\ E-mail: martin.ertl@uniqa.at
}

\begin{abstract}
What is the impact of economic convergence and of structural breaks like the global financial crisis on insurance development? We employ a dynamic panel data GMM framework on a sample of eight Central- and Eastern European countries in the period between 1994 and 2014. Particular emphasis is on the relationship between economic growth and growth of life and non-life insurance during the transition period. A variety of enabling environment indicators influences insurance growth, and we find considerable differences between the life and non-life insurance market. In addition, we identify an insurance convergence effect that is significant before the 2008/2009 financial crisis. We investigate how these dependencies changed in the aftermath of the crisis.
\end{abstract}

The Geneva Papers (2017) 42, 323-347. doi:10.1057/s41288-017-0043-6

Keywords: Central and Eastern Europe; insurance; growth; convergence

Article submitted 3 November 2015; accepted 25th November 2016; published online 1 March 2017

The online version of this article is available Open Access

\section{Introduction}

Insurance development in Central and Eastern Europe (CEE) has gone a long way since the fall of the Iron Curtain. In 1989, the presence of Western European insurance companies was almost negligible in the transition region. Two and a half decades later, the picture had dramatically changed: For example, the two largest Austrian insurance groups were operating businesses in 15, respectively 20, countries in CEE in 2015 and a lot of other Western European insurers (including big players form Germany, Italy, the Netherlands and Scandinavia) have a similarly large presence in the region. In the period between 2000 and 2014, average real GDP growth was 2.9 per cent in the eight CEE countries subject to our study. At the same time, annual growth of total insurance premiums averaged 4.6 per cent. In the corresponding period, GDP grew by 1.4 per cent on average in the EU-15, and annual insurance premium growth was 2.5 per cent. The CEE countries which had on average a GDP per capita of less than one-third that of Western Europe (EU-15) in 2000 experienced higher average GDP growth and higher total insurance premium growth during the period. For Western European insurance groups, the economic and insurance development in Central and Eastern Europe is an important - for some of them vital issue. Business strategies in CEE are based on the firm belief in economic convergence and the corresponding catch-up in insurance business. Faced with maturing home markets, insurers expect to generate excess growth of business in CEE. For example, the group report of an Austrian insurance firm stated in 2013 that "there is a significant need to catch 
up with regard to insurance products [in CEE] [...]. Whereas an Austrian invests an average of 1925 euros annually in insurance security, the corresponding per capita spend on coverage in Albania is a meagre 20 euros." 1

In the run-up to the 2008/2009 financial crisis, economic growth was buoyant and patterns of growth were largely homogenous in CEE, enabling insurers a rapid business expansion in the region. There was double-digit annual growth in real premiums in most years between 1994 and 2007. The new EU Member States (NMS') gained from the EU Eastern expansion in 2005 and 2007, and the region as a whole profited from capital inflows during the pre-crisis years. $^{2}$ The 2008/2009 economic and financial crisis triggered a sudden stop, and the CEE region was among the worst hit by the crisis. In 2009, the average contraction in real GDP was 6.3 per cent in the eight countries subject to our investigation. Total insurance premiums fell by 10.0 per cent in the 2009 crisis year and kept contracting until 2014. Figure 1 shows the rising insurance penetration (between 1994 and 2008) and the subsequent fall (between 2008 and 2014) in CEE in comparison to the development in Western Europe.

Nowadays, insurers face higher uncertainty about the growth prospects of their businesses in CEE. First, economic growth is likely distributed more unevenly amid the absence of common growth drivers. The NMS have resumed economic growth. Poland has been one of the few countries that avoided a recession in 2009 and quickly returned to robust growth. Likewise, the recovery in the Czech Republic, Hungary and Romania appears to be sustainable now. Potential growth estimates centre around 3 per cent for the NMS, widely considered as "the new normal" for these economies. ${ }^{3}$ South-Eastern Europe is heterogeneous: Croatia had six years of recession and has not yet realised gains from EU accession in 2013. Some countries have EU accession negotiations or candidate status, but face a broad mix of weak institutions and policies, high unemployment and deficient labour markets and potentially low growth in a state without economic reform.

In this paper, we reconsider the drivers of insurance development in a panel of CEE countries. We emphasise the relationship between economic growth and growth of insurance premiums ("demand-leading" framework ${ }^{4}$ ). Further factors delineate the "enabling environment" 5 for insurance activities, including a proper monetary framework, a complementary development of the banking sector and the inflow of foreign capital in the financial sector. We introduce policy variables which are particularly suited for describing the convergence process in insurance markets. The CEE data set comprises eight countries with data from 1994 to 2014. We use a sample of 13 Western European countries for the same period to demonstrate different or even absent dependencies in matured insurance markets. The insurance premium data is taken from the Swiss Re sigma database. ${ }^{6}$ In our empirical analysis, we distinguish between the pre-crisis period (1994-2008) and a post-

\footnotetext{
${ }^{1}$ UNIQA Group Report 2013.

2 Staff members from the IMF's European Department described large capital inflows in the financial sectors as the predominant and common growth driver for the region during that period (Bakker and Klingen 2010).

${ }^{3}$ See, for example, long-term forecasts in the statistical appendix of the IMF World Economic Outlook (2015, pp. 171-174).

4 Outreville (2011).

${ }^{5}$ Beck et al. (2008).

${ }^{6}$ Source: Swiss Re, sigma database. All rights reserved.
} 


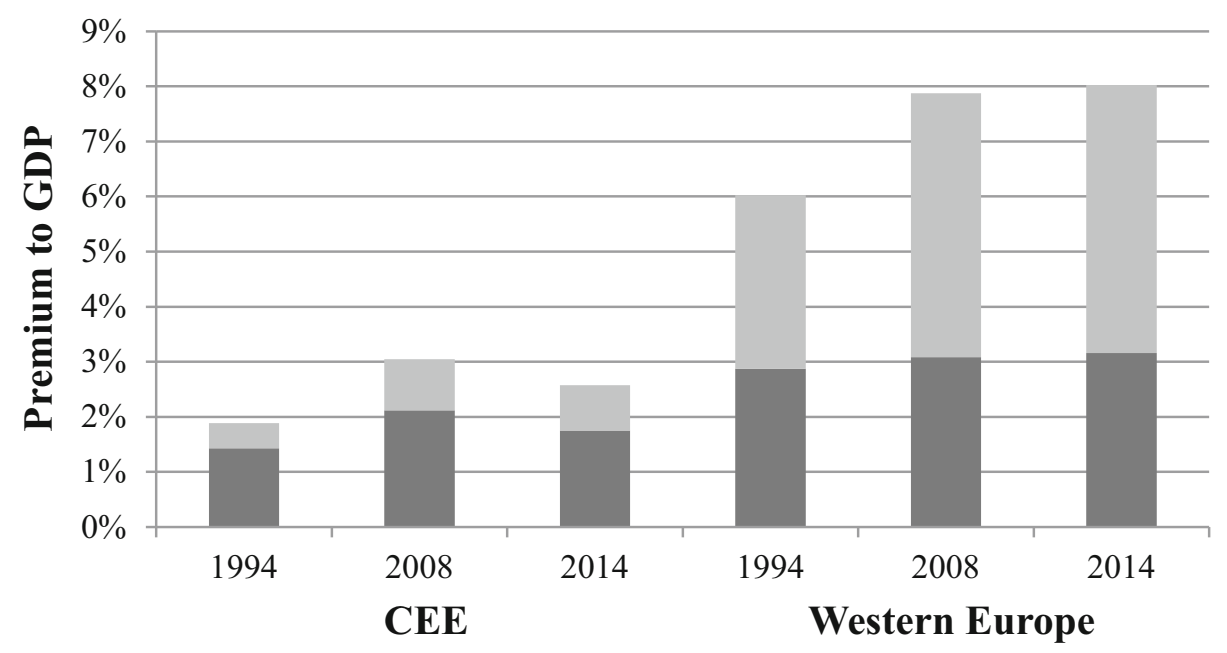

Non-Life Life

Figure 1. Insurance penetration in CEE and Western Europe. Source: Swiss Re, sigma database. All rights reserved.

crisis period (2010-2014) contributing a rather new notion to this stream of literature. Development theory would imply that countries with lower income per capita have higher growth prospects, and a catch-up with richer countries also implies a higher growth rate of insurance premiums. New convergence variables are included in our regressions, and they largely confirm this hypothesis for the period before the 2008/2009 financial crisis. We investigate the post-crisis changes in the economic growth and insurance link as well as changes in the relationship with the enabling environment indicators. In addition, we make a careful distinction between the life and the non-life insurance markets and find differing results for the two segments. Finally, we cross-check the main findings with the Western European sample. Empirical results are not robust and cannot be replicated for the mature insurance markets in Western Europe.

This paper contributes to the empirical literature on insurance development in several aspects. Our recent data set (extending until 2014) allows us to exploit the impact of the 2008/2009 financial crisis on life as well as non-life insurance development and to investigate changes compared to the period before the crisis. We improve the identification of the convergence effect vis-à-vis the existing literature. Our specifications allow for a straight interpretation of the economic growth and insurance link. The set-up enables a comparative investigation to Western Europe. We argue that our econometric framework more properly addresses endogeneity issues in the economic growth and insurance link in CEE. Insurance development in CEE is vital not only for the local markets but also for Western European insurers that are exposed to the region, and our findings might also be relevant for other emerging or developing economies.

This paper is structured as follows. The "Existing literature" section provides an overview of the existing literature and the "Data" section proceeds with the data 
description. In the "Empirical strategy and results" section we present our empirical model and results and the last section concludes.

\section{Existing literature}

We aim to contribute to the literature on insurance development that belongs to the vast literature about the role of finance in economic development as pioneered, for example, by Levine and various co-authors. ${ }^{7}$ For theoretical considerations, a model on consumer demand for insurance was provided by the seminal work of Yaari. ${ }^{8}$ Webb et al. ${ }^{9}$ developed a general equilibrium framework incorporating the insurance sector in a Solow-Swan growth model.

The empirical financial development literature based on cross-country regressions is divided into two main branches. ${ }^{5}$ One branch tries to examine the drivers of financial development, with particular focus on the contribution of policy to financial development. The performance of the financial sector depends on a sound "enabling environment" influenced by policies. The second branch tries to examine the impact of financial development on economic and social development. If good policies contribute to an enabling environment of financial development (an intermediate objective of policy) and if financial development contributes to long-term growth (the final objective of policy), then good policies contribute to the final objectives. ${ }^{10}$ Our paper explores the factors that influence insurance activity and therefore clearly belongs to the first branch examining the drivers of financial development. The results chain is related to the distinction between a "demand-leading"-approach and a "supply-leading"-framework. ${ }^{4}$ According to this distinction, we set up a "demand-following"-framework in the empirical section.

Important determinant factors of insurance include income, wealth, the price of insurance, anticipated inflation, real interest rates, the role of the stock market, unemployment, demographic factors, risk aversion, the educational level, religion and culture, financial development, market structure, social security, the legal and regulatory environment and political risk and governance. ${ }^{11}$ The drivers of the development of the life insurance sector have been grouped in four major categories: (1) economic variables, (2) demographic variables, (3) social/cultural variables and (4) institutional/market structure variables. ${ }^{12}$ Most of the existing empirical literature investigates the demand for life insurance (in particular in the United States). ${ }^{13}$ This contrasts with the fact that in the transition and emerging economies - the focus of our paper - the insurance market is mostly dominated by the non-life insurance segment. To that effect, our analysis contributes an assessment of the drivers of both the life and non-life insurance sectors to the existing empirical literature and also enables a comparison. Outreville contributed three early cross-country regressions of

\footnotetext{
${ }^{7}$ King and Levine (1993); Levine and Zervos (1998); Levine (1998, 1999, 2002).

${ }^{8}$ Yaari $(1964,1965)$.

${ }^{9}$ Webb et al. (2002).

${ }^{10}$ With respect of the chain of causality see Figure 1 in Beck et al. (2008).

${ }^{11}$ Outreville (2011); Feyen et al. (2011).

${ }^{12}$ Feyen et al. (2011), see Table 1.

13 Outreville (2011, p. 12); Feyen et al. (2011, p. 3).
} 
developing countries. ${ }^{14}$ Other more recent empirical studies about insurance in developing countries are Catalan et al., Impavido et al. and Davis and $\mathrm{Hu} .{ }^{15} \mathrm{Hwang}$ and Greenford as well as Sen $^{16}$ studied factors effecting life insurance in Asian countries.

Arena ${ }^{17}$ and Han et al. ${ }^{18}$ belong to the second branch of literature (as described above), investigating the impact of insurance development on economic growth. Both papers are closely related to our paper because of distinctions between the relationship in developed and developing countries. Both cover the life as well as the non-life insurance segments. Arena ${ }^{17}$ employs a dynamic panel model using data of 55 countries between 1976 and 2004. The effect on economic growth is driven by high-income countries in the case of life insurance, while in the case of non-life insurance, its impact is driven by both high-income, and developing countries (where high-income countries display a larger effect). In addition, the author tests for non-linear effects by evaluating the insurance impact at different development stages and finds that both life and non-life insurance have a bigger and statistically significant impact on economic growth at low and middle levels of economic development. Han et al. ${ }^{18}$ analysed the relationship between insurance development and economic growth by employing GMM models on a dynamic panel data set of 77 economies for the period 1994-2005. A distinction between developed and developing economies and life and non-life insurance businesses is also incorporated in the analysis. The authors draw the conclusion that insurance development is statistically significant and positively correlated with economic growth. There is a fairly large increase in economic growth of about 4.8 per cent in response to a 1 per cent increase in (the log of) total insurance density. For non-life insurance, the effect is gradually smaller, while the magnitude of the effect of the life insurance variable increases. They also found that, in developing economies, the overall development of life insurance and non-life insurance play a much more important role for economic growth than for the developed economies. The results of both papers ${ }^{19}$ are in line with our findings about a differing and weaker relationship between premium and economic growth in developed economies as compared to the developing world. Beck and $\mathrm{Webb}^{20}$ and Feyen et al. ${ }^{21}$ describe drivers of insurance development (the first branch of literature according to the distinction described above). There is no separate analysis of developing countries. Back and Webb ${ }^{24}$ cover only the life insurance market. They investigate the influence of economic, demographic and institutional factors on life insurance consumption. The data panel covers 68 economies between 1961 and 2000. In the baseline regression, a 10 percent increase in real income per capita increases life insurance penetration by 5.7 percent; when income per capita is replaced by a proxy for permanent income, the rise in life insurance penetration increases in size. In addition, price stability, banking sector development and the old dependency ratio are identified as consistently positive influences on life insurance. Similarly, the

\footnotetext{
14 Outreville (1990), (1992), (1996).

15 Catalan et al. (2000); Impavido et al. (2003); Davis and Hu (2005).

${ }^{16}$ Hwang and Greenford (2005); Sen (2008).

17 Arena (2008).

${ }^{18}$ Han et al. (2010).

19 Arena (2008), Han et al. (2010).

${ }^{20}$ Beck and Webb (2003).

${ }^{21}$ Feyen et al. (2011).
} 
drivers of insurance development are investigated in Feyen et $a l^{21}$ in a panel of 90 countries from 2000 to 2008 . Per capita income and inflation have statistically significant positive and negative effects (though the coefficients vary a lot across specifications) on life and non-life sector premiums. Further important explanatory factors are demographic, social and institutional variables. Our investigation combines the separate discussion of the economic growth and insurance link in developed and emerging countries (Arena, ${ }^{17}$ Han et $a l^{18}$ ) with an insurance development framework (Beck and Webb, ${ }^{20}$ Feyen et al. ${ }^{21}$ ).

The literature on insurance development in CEE is also divided into, on the one hand, those examining the drivers of the insurance development (Kjosevksi, ${ }^{22}$ Phutkaradze, ${ }^{23}$ and $\left.\operatorname{Dragos}^{24}\right)$, and on the other hand, others investigating the effect of insurance activity on economic development (Curak et al., ${ }^{25}$ Njegomir and Stojic ${ }^{26}$ ). Kjosevski ${ }^{22}$ investigated determinants of life insurance in a fixed effects panel data model in 14 countries in Centraland South-Eastern Europe between 1998 and 2010. GDP per capita has a statistically significant and positive effect on life insurance penetration and density (premium per capita). Recently, Phutkaradze ${ }^{23}$ regressed economic growth on measures of insurance penetration in a fixed effects panel model of 10 Central and Eastern European countries in the 2000-2012 period. The author failed to disentangle any statistically significant relationship. Dragos ${ }^{24}$ emphasised the differential effects of influence factors of life and non-life insurance demand in emerging Asia and Central and Eastern Europe. The data are based on a sample of $10 \mathrm{CEE}$ countries between 2000 and 2011. The fixed and random effects models find statistically significant and positive (though small) impacts of (nominal) GDP per capita on life and non-life insurance density in CEE. Curak et al. ${ }^{25}$ explore the impact of total, life and non-life insurance growth on economic growth in a panel of 10 Eastern European EU member countries over the period of 1992-2007. OLS and 2SLS estimates yield statistically significant and positive coefficients for total insurance growth. The coefficients are smaller for life and larger for non-life insurance. The ex-Yugoslavian region is examined in Njegomir and Stojic ${ }^{26}$ between 2004 and 2008. In a fixed effect panel data regression, gross written premiums have a statistically significant and positive effect on GDP growth. Little related research explicitly takes into account insurance convergence dynamics in CEE at different development stages. Enz, ${ }^{27}$ Ward and Zurbruegg ${ }^{28}$ and Zheng et al. ${ }^{29}$ discussed convergence in the broader context of the S-curve relationship between per capita income and insurance. Without incorporating the insurance market in their analysis, Fink et al. ${ }^{30}$ investigated the impact of financial sector segments at different levels of transition in a sample of nine countries in CEE between 1996 and 2000. The production function approach shows that transfer mechanisms differ in the development cycle. For EU accession countries, financial sector development (domestic credit expansion) and the bond markets stimulate economic growth over early years of transition, while other factors

\footnotetext{
${ }^{22}$ Kjosevski (2012).

${ }^{23}$ Phutkaradze (2014).

${ }^{24}$ Dragos (2014).

${ }^{25}$ Curak et al. (2009).

${ }^{26}$ Njegomir and Stojic (2010).

${ }^{27}$ Enz (2000).

${ }^{28}$ Ward and Zurbruegg (2002).

${ }^{29}$ Zheng et al. (2009).

${ }^{30}$ Fink et al. (2009).
} 
(education, capital accumulation) dominate at later development stages. Kozarevic et al. ${ }^{31}$ provide an overview about insurance development, economic transition and the relationship with EU integration in ten countries in South-Eastern Europe between 2001 and 2010. Some aspects of insurance development (insurance penetration and density, share of life insurance) depend on the level of economic development, while other aspects (legal and institutional framework, solvency standards) tend to depend on the process of EU integration.

In addition to confirming existing findings about CEE, we introduce explicit convergence terms and analyse differential aspects to developed markets both in life and non-life insurance. We improve methodically in addressing endogeneity problems within the GMM framework. The existing empirical research has not placed emphasis on the period after the 2008/2009 financial crisis. The empirical part of this paper investigates separately the period before the 2008/2009 financial crisis and after the crisis including data until 2014. This is a rather new notion in empirical research on insurance development in CEE.

\section{Data}

The data sample includes eight countries in Central and Eastern Europe: Bulgaria, Czech Republic, Croatia, Hungary, Latvia, Poland, Romania and Slovenia. Data are annual and stretch from 1994 to 2014 (21 years). There was a period of rapid transition followed by the downturn in 2008/2009 and a heterogeneous recovery afterwards (as described in "Introduction" section). The Western European sample covers 13 countries including Austria, Belgium, Denmark, Finland, France, Germany, Italy, the Netherlands, Norway, Spain, Sweden, Switzerland and United Kingdom. Table 9 in the Appendix provides a list of the variables, definitions and sources. Insurance premium data are from the Swiss $\mathrm{Re}$ sigma database. ${ }^{32}$ Total insurance premiums include the life and non-life direct insurance premiums. The relative composition is different for CEE and Western Europe (Figure 1). Life insurance makes up a relatively small part of total insurance in CEE (around 1/3 in 2014), while its part in the total market was around two-thirds in Western Europe countries in 2014. The non-life insurance data include the health insurance segment. We have no evidence that the inclusion of the health insurance segment distorts our empirical results, since it represents a small and negligible part of the insurance market in CEE. In 2014, the health insurance sector comprised around 3 per cent of the non-life insurance market in the countries comprising our CEE sample (excluding Slovenia and Latvia), while the health insurance market is relatively larger in Western Europe (greater than 10 per cent of total premiums). ${ }^{33}$ The non-life insurance market in particular in its early stages was dominated by motor insurance (and still is for poorer countries in the CEE sample), while today, property and casualty $(\mathrm{P} \& \mathrm{C})$ insurance takes an increasing part of the total insurance premiums. For example, in Poland, the Czech Republic and Hungary, motor third-party

\footnotetext{
${ }^{31}$ Kozarevic et al. (2013).

32 Source: Swiss Re, sigma database. All rights reserved.

33 Source: National supervisory authorities and associations, Insurance Europe: European Insurance-Key Facts 2015.
} 
liability (MTPL) and other non-life each make up around 30 per cent of total premiums, while life insurance premiums contribute between 40 and 50 per cent to total premiums. ${ }^{34}$ Growth rates are generally defined in real terms (nominal growth rate minus inflation) and as percentage annual changes. Real GDP growth, GDP per capita (in U.S. dollar purchasing power parities) and the inflation rate are taken from the IMF World Economic Outlook (October 2015). The real interest rate is the lending rate or, if unavailable, the money market rate taken from the IMF International Financial Statistics (IFS) database. Real credit growth refers to inflation-adjusted claims by deposit banks and other financial institutions on the domestic private sector (IMF IFS database). Real (mortgage) lending for house purchase is sourced from the European Central Bank. The transition variables in the model are calculated from the EBRD transition indicators and an indicator (cost of business start-up procedures) from the Doing Business project of the World Bank. Vehicle registrations (ACEA) and the "other investment" item from the financial account (balance of payments data from the IMF IFS) are also explanatory factors. The old-age dependency rate is also from the World Bank database.

Insurance data are not available (from our source) or scarce for some of the Western Balkan countries (Serbia's time series starts in 2003). Overall, our sample is a good proxy for the CEE region. It includes most new EU member states (with the exception of Slovakia, Lithuania and Estonia) and Slovenia and Croatia representing the former Yugoslav republics. CEE is defined as including continental European countries in the East of the European Union before the enlargement of the EU. Turkey is not included in the sample. Table 1 reports descriptive statistics for the growth rate of total (real) insurance premiums, real GDP growth and GDP per capita for CEE.

On average, insurance premium growth was highest in Romania (13.4 per cent) and Latvia (8.6 per cent). The countries with the highest standard deviation for insurance growth are Latvia (18.9 per cent) and Bulgaria (18.8 per cent). The maximum premium growth was registered in Slovenia (43.3 per cent in 1995) while the biggest drop was recorded in Bulgaria ( -61.0 per cent in 1997).

\section{Empirical strategy and results}

Insurance activity depends on an enabling environment. ${ }^{5}$ We introduce enabling environment indicators (EEIs) which include the monetary framework, the banking sector development, complementary markets (automobile) and international financial capital inflows. Transition and doing business indicators are added to measure the policy impact in improving the enabling environment. These factors foster the development of the insurance sector and, in turn, insurance development drives the ultimate policy goal - welfare-improving economic development and a catch-up in incomes per capita. Our set-up allows for an explicit exploration of the convergence process during which insurance growth might exceed the catch-up dynamics in the entire economy. The focus on economic growth and other macroeconomic variables relates the set-up to a "demand-leading" framework. ${ }^{4}$ An increase in economic activities in the entire

\footnotetext{
${ }^{34}$ Source: National supervisory authorities and associations.
} 
Martin Ertl Insurance Convergence and Post-crisis Dynamics in CEE

Table 1 Summary statistics

\begin{tabular}{|c|c|c|c|}
\hline Variable & Insurance premium growth & Real GDP growth & GDP per capita \\
\hline Obs & 167 & 174 & 175 \\
\hline Mean & 6.286 & 2.807 & 16,764 \\
\hline $\mathrm{SD}$ & 13.144 & 3.795 & 6576 \\
\hline Min & -61.016 & -14.186 & 5753 \\
\hline $\operatorname{Max}$ & 43.256 & 11.621 & 31,480 \\
\hline \multicolumn{4}{|l|}{ Bulgaria } \\
\hline Mean & 4.719 & 1.697 & 11,769 \\
\hline SD & 18.775 & 4.364 & 4191 \\
\hline Min & -61.016 & -8.043 & 6917 \\
\hline $\operatorname{Max}$ & 29.729 & 6.907 & 18,502 \\
\hline \multicolumn{4}{|c|}{ Czech Republic } \\
\hline Mean & 5.512 & 2.386 & 22,381 \\
\hline SD & 5.486 & 2.853 & 6096 \\
\hline Min & -4.027 & -4.842 & 13,841 \\
\hline $\operatorname{Max}$ & 16.612 & 6.877 & 31,480 \\
\hline \multicolumn{4}{|l|}{ Croatia } \\
\hline Mean & 1.852 & 2.358 & 16,198 \\
\hline SD & 6.876 & 3.559 & 4548 \\
\hline Min & -17.098 & -7.384 & 8623 \\
\hline Max & 9.976 & 6.634 & 21,476 \\
\hline \multicolumn{4}{|l|}{ Hungary } \\
\hline Mean & 3.258 & 2.257 & 18,200 \\
\hline SD & 8.278 & 2.581 & 5035 \\
\hline Min & -11.886 & -6.551 & 10,591 \\
\hline $\operatorname{Max}$ & 17.543 & 4.789 & 26,075 \\
\hline \multicolumn{4}{|l|}{ Latvia } \\
\hline Mean & 8.577 & 3.956 & 14,541 \\
\hline SD & 18.923 & 5.808 & 6475 \\
\hline Min & -35.692 & -14.186 & 5753 \\
\hline Max & 39.414 & 11.621 & 24,620 \\
\hline \multicolumn{4}{|l|}{ Poland } \\
\hline Mean & 7.379 & 4.219 & 15,851 \\
\hline SD & 11.658 & 1.801 & 6017 \\
\hline Min & -16.861 & 1.205 & 7436 \\
\hline Max & 31.222 & 7.202 & 26,403 \\
\hline \multicolumn{4}{|l|}{ Romania } \\
\hline Mean & 13.435 & 2.796 & 12,761 \\
\hline SD & 16.192 & 4.483 & 4752 \\
\hline Min & -11.746 & -7.067 & 6930 \\
\hline Max & 36.781 & 8.459 & 20,698 \\
\hline \multicolumn{4}{|l|}{ Slovenia } \\
\hline Mean & 5.663 & 2.745 & 22,668 \\
\hline SD & 10.156 & 3.219 & 6248 \\
\hline Min & -6.536 & -7.797 & 12,604 \\
\hline $\operatorname{Max}$ & 43.256 & 6.942 & 30,825 \\
\hline
\end{tabular}

GDP per capita in USD purchasing power parity.

Czech Republic Real GDP growth: 2 values missing, GDP per capita: 1 value missing.

Latvia Insurance Premium Growth: 1 value missing.

Source: IMF World Economic Outlook; Swiss Re, sigma database. All rights reserved. 
economy has a beneficial effect on insurance business. Higher output implies higher income to households and increasing sales and profit for firms and, hence, higher spending on insurance. Higher economic growth induces faster accumulation of wealth and higher demand for spending part of the available income on insurance. Firms seek P\&C insurance for new establishments, equipment and structures. Higher wealth also implies a higher propensity to save and thus leads to higher demand for life insurance products.

Parts of the existing literature define the insurance variable as insurance density (premiums per capita) or penetration (premiums to GDP). ${ }^{35}$ Here, our insurance variable is defined as the annual growth rate in real premiums. The definition enables a straightforward interpretation of the insurance coefficient similar to a "multiplier": GDP growth of $x$ percentage points leads (on average) to $y$ percentage points of insurance premium growth. Short-term GDP growth is also more convenient for investigating the shorter period after the financial crisis. The Im-Pesaran-Shin test rejects unit roots in the premium growth time series.

The bi-directional nature of the economic growth and insurance relationship involves an endogeneity problem (reverse causality and simultaneity bias) that we address with instruments in a linear dynamic panel data model. The dynamic term of the model measures the dependence on its own past realisations. The baseline regression to be estimated is as follows:

$$
\text { PREM_CHNG }{ }_{c t}=\alpha+\rho \text { PREM_CHNG }{ }_{c, t-1}+\beta \mathrm{GDP}_{-} \mathrm{CHNG}_{c t}+X_{c t}^{\prime} \gamma+f_{c}+u_{c t}
$$

PREM_CHNG ${ }_{c t}$ measures the growth rate of real insurance premiums in country $c$ at time $t$. In the subsequent specifications, PREMTOT_CHNG ${ }_{c t}$ denotes the real growth rate of total insurance premiums, and PREMLIFE_CHNG ${ }_{c t}$ and PREMNONLIFE_CHNG ${ }_{c t}$ are the real growth rates of life and non-life insurance premiums. The growth rate of real gross domestic product of country $c$ in year $t$ is denoted by GDP_CHNG ${ }_{c t}$, and $\beta$ is the coefficient of main interest. GDP growth can also be viewed as control variable drawing the focus to policy variables included in $X_{c t}$ in our specification. ${ }^{5} X_{c t}$ includes a set of further macroeconomic variables, EEIs and convergence indicators, $f_{\mathrm{c}}$ is the country-fixed unobserved effect and $\mathrm{u}_{\mathrm{it}}$ denotes the error term. Within $X_{c t}, \mathrm{GDP} \_\mathrm{PC}_{c t}$ denotes per capita gross domestic product based on purchasing power parity (PPP). The variable controls for convergence: for higher levels in per capita GDP we expect lower insurance premium growth. Subsequently, we introduce the EBRD transition index $\left(\right.$ TRANSITION $\left._{c t}\right)$ as an additional control for economic and insurance convergence in the model. We assume that the convergence variables absorb changes in insurance regulation. Similarly, the cost of business start-up procedures (START_UP ${ }_{c t}$ ) from the World Bank's Doing Business project controls for convergence and growth-enhancing reform. Further macroeconomic explanatory variables included are the inflation rate $\left(\mathrm{CPI} \mathrm{CHNG}_{c t}\right)$, the unemployment rate $\left(\mathrm{UNEMPL}_{c t}\right.$ ) and the real interest rate (INTEREST $\mathrm{I}_{c t}$ ). The inflation-adjusted growth rates of total credit $\left(\right.$ CREDIT $\left._{c t}\right)$ and of credit for house purchase $\left(\right.$ MORTGAGES $_{c t}$ ) control for banking sector development. Banking sector development also depends on foreign capital inflow, in particular, debt inflow which is recorded in the category "other investment"

${ }^{35}$ Compare to the existing literature section or Appendix in Outreville (2011). 
$\left(\right.$ FOREIGN $\left._{c t}\right)$ in the financial account of the balance of payments. ${ }^{36}$ CARS $_{c t}$ is the percentage annual change in vehicle registrations. GDP_CHNG , $_{c t}$, and the variables in $X_{c t}$ are treated as exogenous variables. We did not find any significant relationship in any specification for the general government fiscal balance, the general government debt and the current account balance and therefore excluded them from our model. We included the old-age dependency ratio $\left(\mathrm{OLD} \_\mathrm{AGE}_{c t}\right)$ in the vector of controls to capture demographic influences. We assume that country-fixed cultural or religious effects are differenced out in our model specification. A detailed description of definitions and sources of the variables is included in Table 9 in the Appendix.

We employ the dynamic panel data GMM estimator as proposed by Arellano and Bond. ${ }^{37}$ The estimator is suggested especially for "small T, large N" panels. Our total sample comprising of CEE and Western Europe has 19 time periods (dropping one period for differencing and one period for lagging from a total of 21 years) and 21 groups (countries). When including the total number of lagged values of the endogenous variable and the differenced values for GDP_CHNG ${ }_{c t}$ and all variables in $X_{c t}$ in the instruments matrix, the number of instruments becomes very large. To avoid over-identification we reduce ("collapse") the number of lagged instruments to one per period for the endogenous variable. Alternatively, we could define GDP_CHNG $c$ as not strictly exogenous and produce "GMM-style" instruments for the variable. It would likely address the reverse causality in the insurance and economic growth variables but it would heavily inflate the number of over-identifying restrictions. Hence, we keep GDP_CHNG ${ }_{c t}$ strictly exogenous but employ the differenced, "IV-style" instrument for the variable. Hansen's J statistic does not indicate overfitting problems in our model. We employ cluster-robust standard errors. Resulting GMM estimates are reported in Table 2.

Table 2 shows estimates for the total sample comprising 21 countries in Western Europe and CEE. The results largely confirm recent findings that we outlined in the literature review. Economic growth has a statistically significant and positive effect on insurance premium growth. The effect of GDP growth on total premiums is larger than unity in regressions 1-5. Column 1 in Table 2 implies that an increase in the GDP growth rate of 1 percentage point leads to an increase of total insurance premium growth of 1.39 percentage points. Subsequent inclusion of additional covariates leaves the growth effect largely unaffected (ranging between 0.95 and 1.39 in columns 1-7 and 9). Higher inflation has a significantly negative effect on insurance growth. The unemployment coefficient has the correct sign (expect column 6) although it is only statistically significant in regressions 7 and 8 . Both a higher real interest rate and higher credit growth have positive and statistically significant effects on insurance premium growth. The GDP per capita level variable is significant and has the expected negative sign in all regressions in Table 2 (with the exception of column 7): Higher GDP per capita influences insurance growth negatively, thereby underlining the insurance convergence effect.

In addition, regressions 8 and 9 include two interaction terms. GDP_CEE $\mathrm{C}_{c t}$ interacts GDP_CHNG ${ }_{c t}$ with a CEE dummy variable that takes the value 1 in case of a CEE country and 0 in case of a Western European country. The coefficient of GDP_CEE $c t$ is positive and

\footnotetext{
${ }^{36}$ Bakker and Klingen (2010).

37 Arellano and Bond (1991).
} 


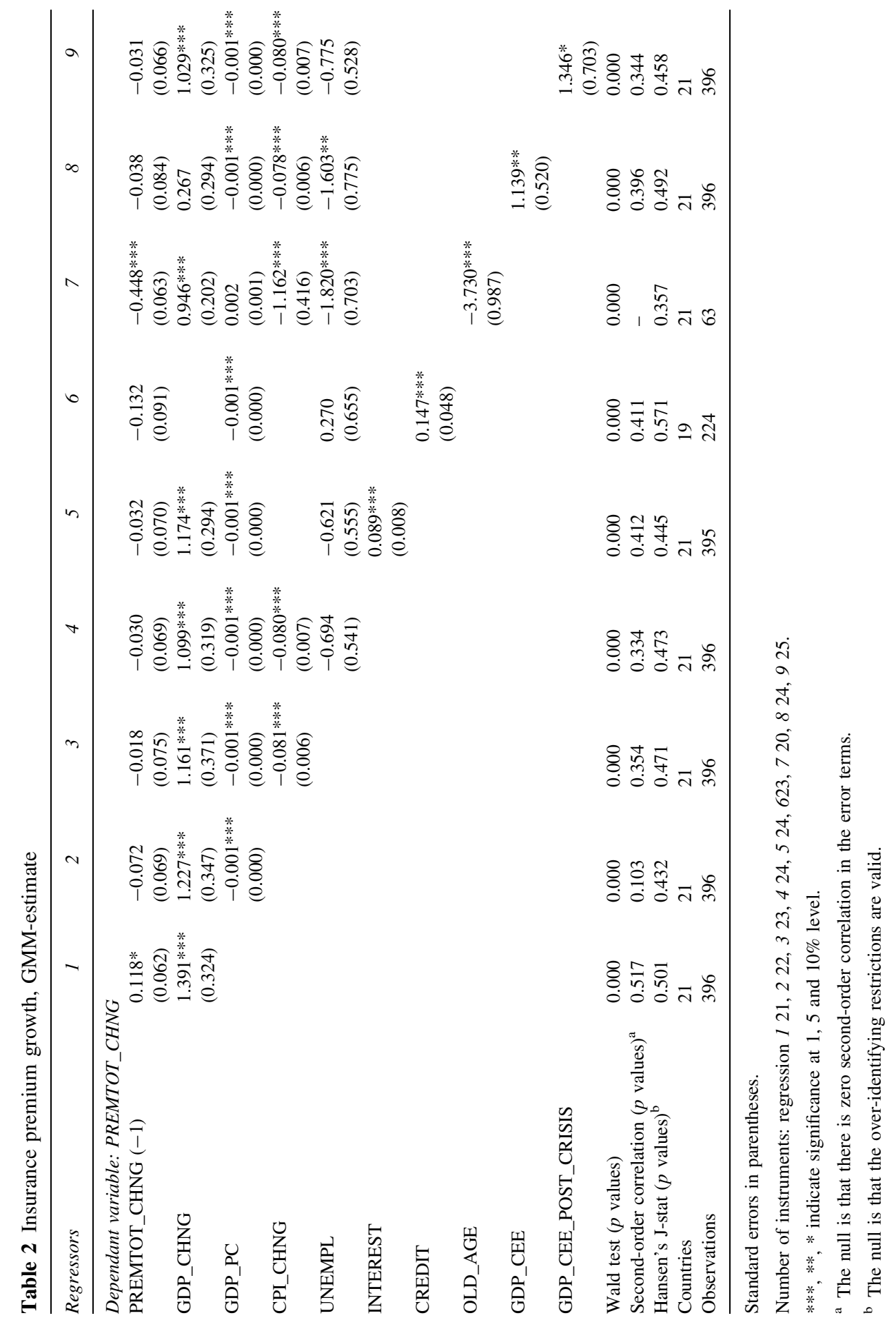


statistically significant. In the same regression (column 8), the coefficient of GDP_CHNG drops to 0.26 and becomes insignificant. Hence, the interaction of GDP growth with the CEE dummy documents that the strong GDP growth and insurance growth relationship in the total sample of Western and CEE countries is driven by the CEE part. The second interaction term (GDP_CEE_POST_CRISIS $c t$ ) multiplies the GDP_CEE $c t$ variable with a dummy that becomes 1 for realisations in the time period between 2010 and 2014 and 0 otherwise. In column 9, the coefficient of the GDP_CEE variable for the post-crisis period is non-significant (at 5 per cent significance level), while the coefficient of GDP_CHNG ${ }_{c t}$ is large and significant. The result seems to suggest that the relationship between GDP growth and insurance changed after the financial crisis as compared to before the crisis. We explore the evidence in more detail in the subsequent analysis.

In a next step, we turn to the analysis of the CEE region. We introduce a differentiation between growth of premiums in life and non-life business and separate our sample into two time periods: 1994-2008 and 2010-2014. The results for the pre-crisis time interval are shown in Tables 3 and 4.

As expected, we find a large and significant effect of GDP growth on life insurance premium growth during the pre-crisis years (Table 3), confirming previous findings in the literature. ${ }^{38}$ The coefficient of the GDP growth variable lies between 2.27 and 3.03 in columns 1-5 and 8. The results contrast with the non-life insurance regressions provided in Table 4. GDP growth did not significantly influence non-life premium growth in the CEE sample between 1994 and 2008. The negative and significant effect of higher inflation exists for both the life and non-life insurance sectors. A sound monetary policy framework with low and stable price development fosters insurance development. We also find that a higher unemployment rate restrained growth in the non-life insurance underwriting. The coefficient of the unemployment rate is consistently negative and statistically significant in Table 4 . Before the financial crisis, we find ample evidence that convergence was an important force driving both life and non-life premiums. A higher level of economic development - ultimately fostered by an enabling environment resulting from growth-enhancing policies - drives down growth in the insurance business in the longer-term (consistent with results on the total Western and CEE sample in Table 2). Accordingly, the coefficient of the TRANSITION $c t$ variable has a negative sign and is statistically significant, thereby supporting the convergence hypothesis. In addition, the effect of the START_UP $c t$ variable is positive and statistically significant. While we were not able to find a significant causal effect going from the rule-oflaw indicator to insurance development, the START_UP ${ }_{c t}$ index, which likely reflects the business climate (barriers to market entry) more directly, appears significant in our regression. ${ }^{39}$ The convergence results are robust across our regressions although not unambiguous: The negative (TRANSITION $c t$ ) and positive $\left(\right.$ START_UP $_{c t}$ ) sign seem to suggest that the convergence effect (driving down insurance growth) outweighs the development effect (promoting insurance growth). Finally, the effect of the level of GDP per capita is statistically significant and negative in the non-life insurance sector (Table 4). A higher real interest rate drives both life and non-life insurance premium growth significantly. Higher real interest rates might coincide with higher productivity and real wage growth and

\footnotetext{
${ }^{38}$ Han et al. (2010); Feyen et al. (2011); Dragos (2014); Kozarevic et al. (2013).

${ }^{39}$ Compare Beck and Webb (2003).
} 


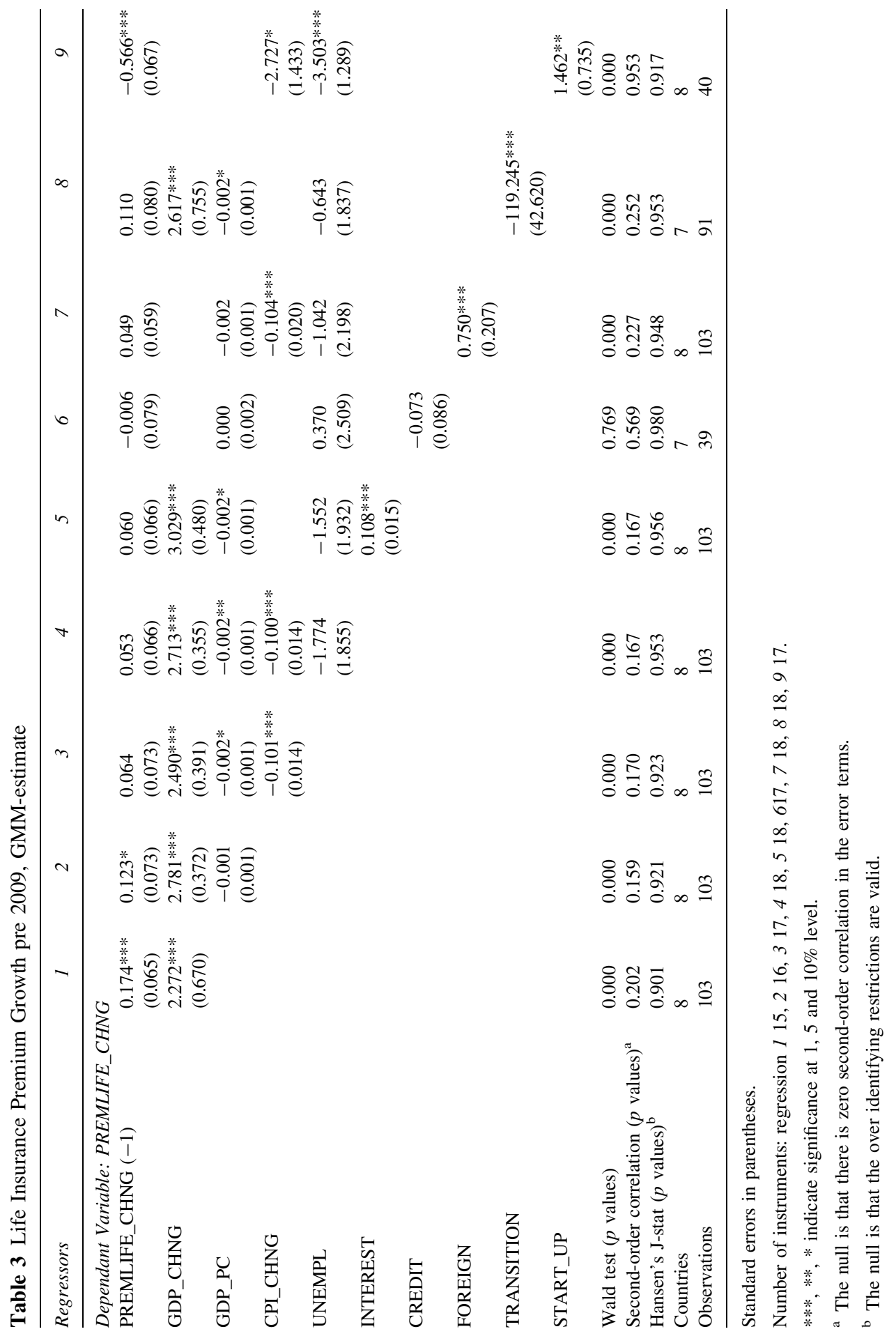




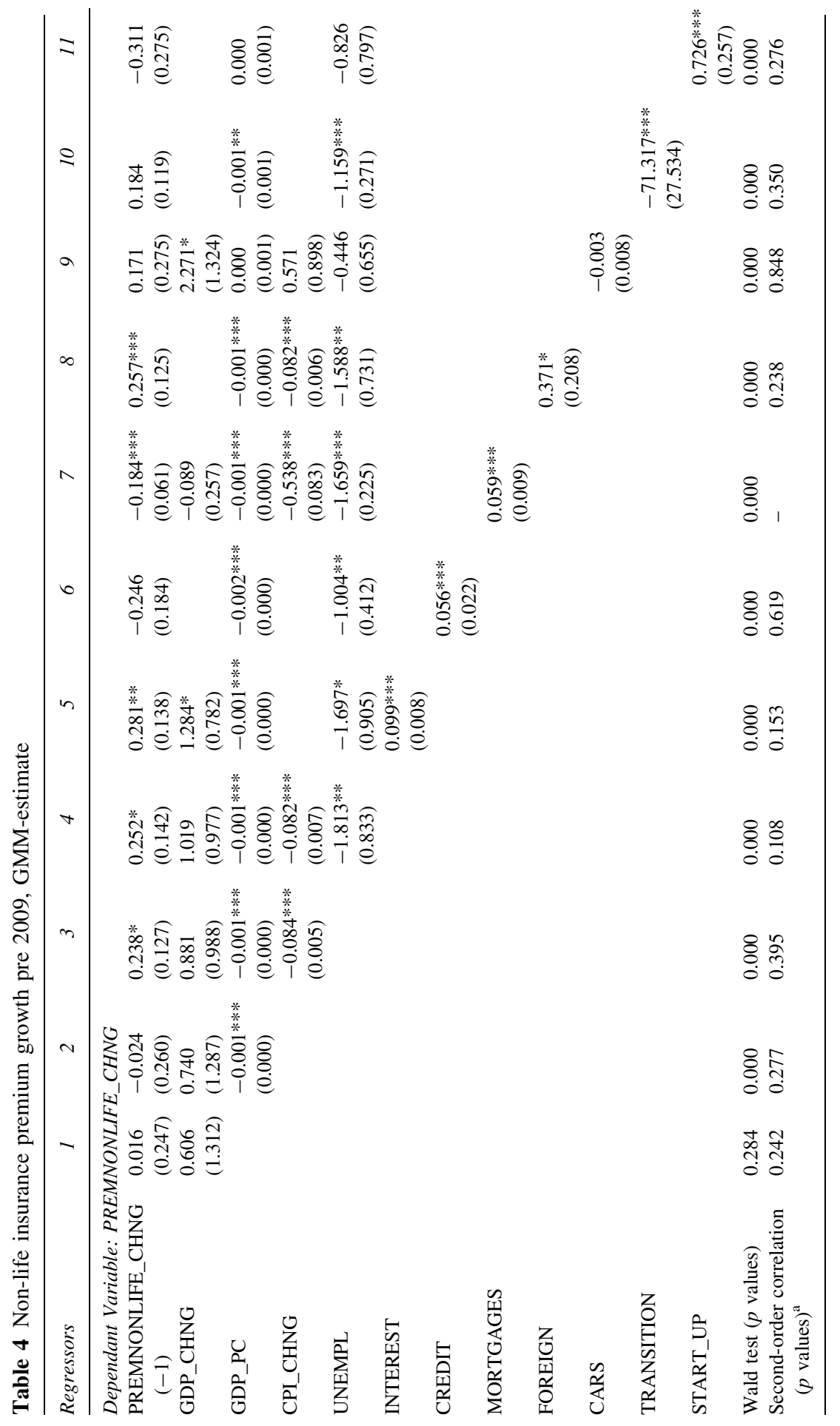




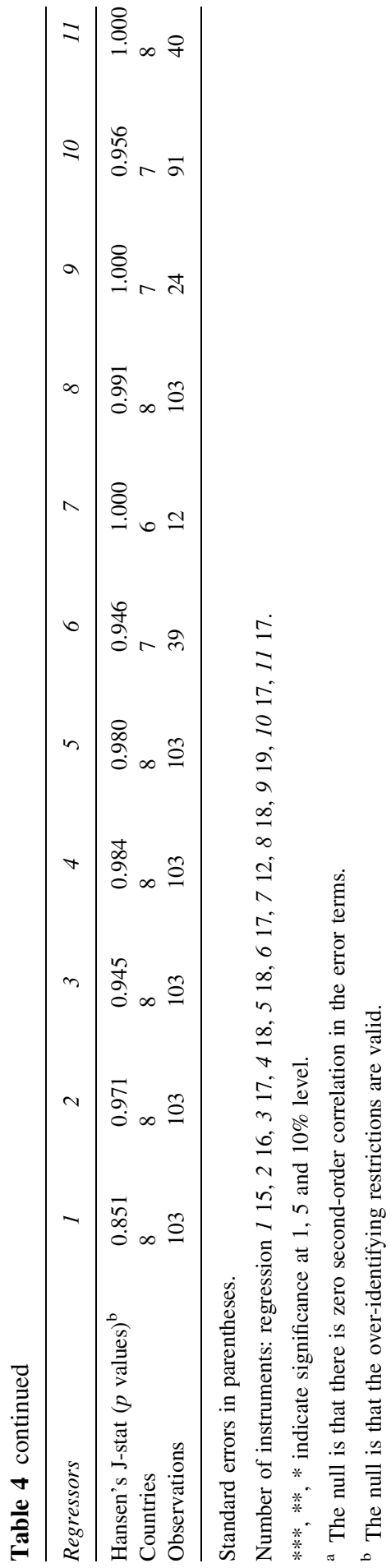


thereby a higher propensity to take out insurance as well as a higher rate of return on life insurances. Banking sector development drove convergence in CEE. ${ }^{30}$ According to our results, total credit and mortgage lending growth was particularly important for the non-life insurance sector. Property and casualty insurance expands alongside higher private homeownership and mortgage lending growth. Hence, while the life business depends more on GDP (and income growth) and on improving wealth, credit expansion can drive the non-life $(\mathrm{P} \& \mathrm{C})$ insurance business. Foreign capital inflow predominately fuelled growth of the life insurance sector, while evidence of a positive effect on non-life insurance is surprisingly weak.

The next part of the section investigates the period between 2010 and 2014. We had argued earlier that, after almost two decades of economic catch-up, the transition countries in CEE were among the worst hit by the 2008/2009 financial crisis and that growth patterns remained less balanced and less homogeneous in the wake of the crisis. Tables 5 and 6 show the regression results for the life and non-life insurance premium growth.

The results suggest a significant impact of the economic and financial crisis on the economic growth and insurance relationship. With regard to the life insurance sector (Table 5), real GDP growth remained a statistically significant driver of premium growth in all specifications, however, the coefficient is smaller than in the post-crisis period and ranges between 1.00 and 2.30 in models $1-6$. The inflation variable kept its negative and statistically significant effect on life insurance premium growth, while the unemployment rate does not significantly influence life insurance premiums (as before 2009). Bearing in mind the considerably shorter post-crisis observation period (compared to before the event), we are not able to detect insurance convergence in the data. Both the TRANSITION $c t$ and the START_UP $c t$ variables do not exhibit a statistically significant influence on the growth rate of life and non-life premiums. As in the period before 2009, the real interest rate has a positive and statistically significant effect on life insurance premium growth, and the coefficient increases (2.80 compared to 0.11 in Table 3 and column 5). Consistent with precrisis results, the coefficient of credit growth is not statistically significant (life insurance), while foreign capital inflows remain a statistically significant determinant.

When looking at non-life insurance premium growth (Table 6), some effects also changed after 2009. We find a positive and statistically significant effect of real GDP growth (column 1), although the coefficient declines and becomes insignificant once other explanatory variables are included in the regression. There is no convergence effect, since both the TRANSITION ${ }_{c t}$ and the START_UP $c$ variables are statistically insignificant. In two regressions (columns 6 and 10 in Table 6), the coefficient of GDP per capita is statistically significant and bears a positive sign, implying some evidence that non-life business is exhibiting higher growth in wealthier countries. Neither the coefficient of the inflation rate is statistically significant (with the exception of regression 7) nor does the unemployment rate exhibit a statistically significant influence on non-life insurance growth contradicting the pre-crisis evidence. On the other side, $\mathrm{CARS}_{c t}$ is statistically significant and exhibits a positive impact on non-life insurance growth. The recovery in vehicle registrations in several CEE countries in recent years was a determinant of the non-life insurance market growth. The results underline the importance of the banking sector channel for insurance development. Credit expansion fuelled non-life insurance growth before the financial crisis, but both growth in the banking sector as well as its impact on non-life insurance activity disappeared afterwards. 


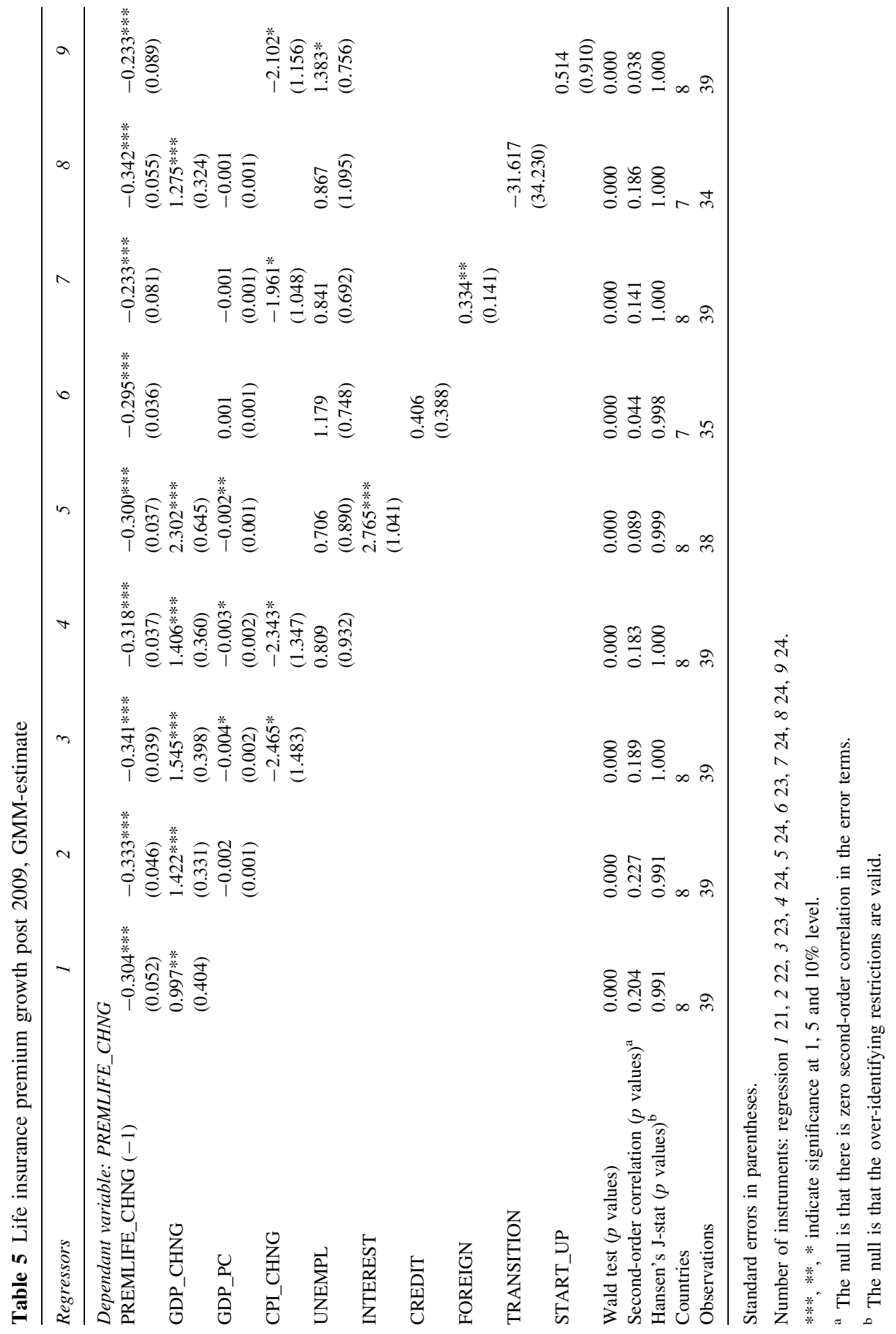




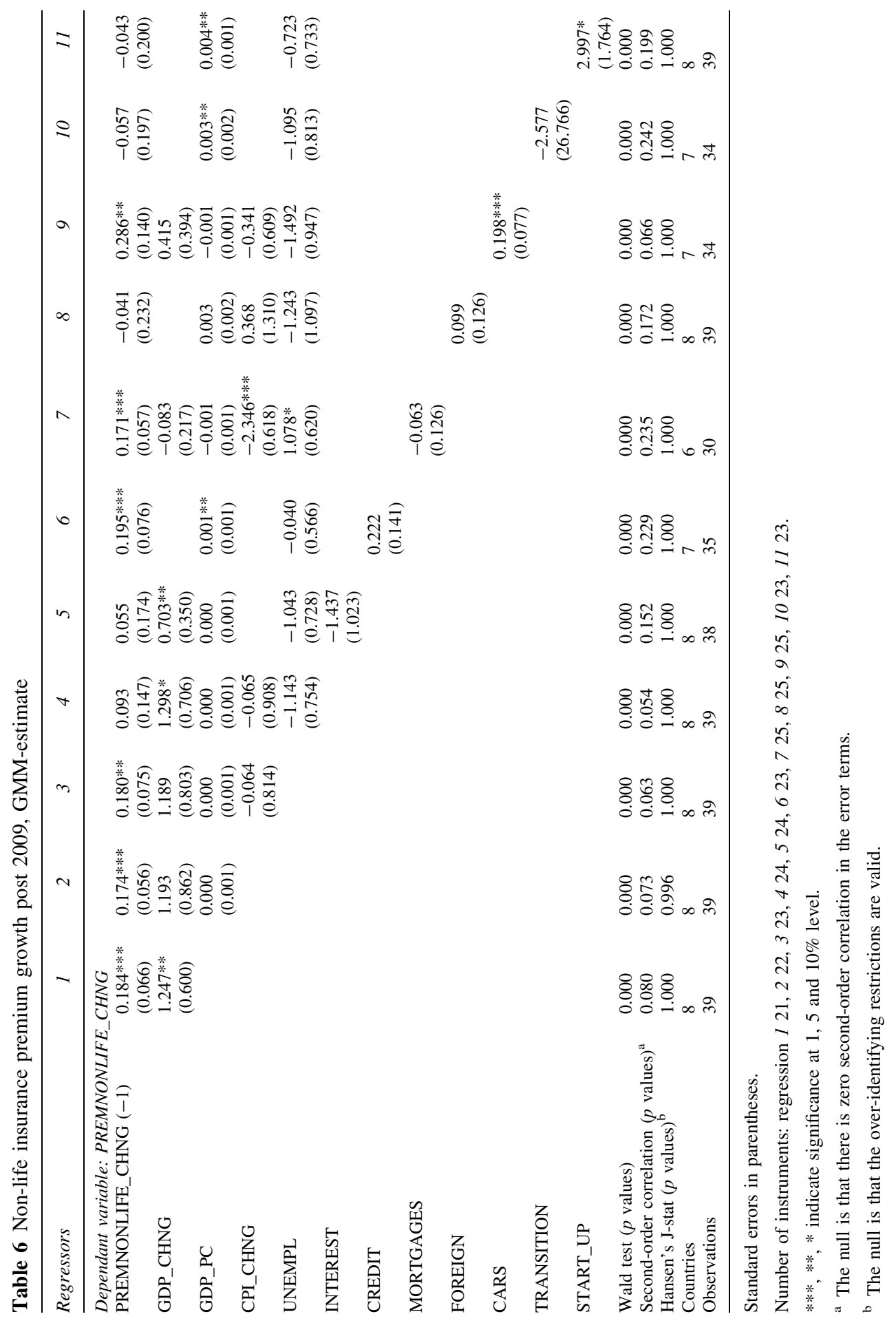


The Geneva Papers on Risk and Insurance-Issues and Practice

342

Table 7 Western Europe life insurance premium growth pre 2009, GMM-estimate

\begin{tabular}{|c|c|c|c|c|c|c|c|}
\hline Regressors & 1 & 2 & 3 & 4 & 5 & 6 & 7 \\
\hline \multicolumn{8}{|c|}{ Dependant variable: PREMLIFE_CHNG } \\
\hline PREMLIFE_CHNG (-1) & $\begin{array}{l}-0.004 \\
(0.147)\end{array}$ & $\begin{array}{l}-0.180 \\
(0.125)\end{array}$ & $\begin{array}{l}-0.160 \\
(0.143)\end{array}$ & $\begin{array}{l}-0.206 \\
(0.139)\end{array}$ & $\begin{array}{l}-0.209^{*} \\
(0.118)\end{array}$ & $\begin{array}{l}-0.540 * * * \\
(0.103)\end{array}$ & $\begin{array}{l}-0.396 * * * \\
(0.085)\end{array}$ \\
\hline GDP_CHNG & $\begin{array}{l}2.807 * * \\
(1.138)\end{array}$ & $\begin{array}{l}1.967 * \\
(1.024)\end{array}$ & $\begin{array}{l}1.611 \\
(1.065)\end{array}$ & $\begin{array}{l}1.826^{*} \\
(1.063)\end{array}$ & $\begin{array}{l}2.122^{*} \\
(0.963)\end{array}$ & & $\begin{array}{l}-3.081 * \\
(1.610)\end{array}$ \\
\hline GDP_PC & & $\begin{array}{l}-0.001 * * \\
(0.000)\end{array}$ & $\begin{array}{l}-0.001^{* *} \\
(0.000)\end{array}$ & $\begin{array}{l}-0.001 \\
(0.000)\end{array}$ & $\begin{array}{l}-0.001 \\
(0.001)\end{array}$ & $\begin{array}{l}0.000 \\
(0.000)\end{array}$ & $\begin{array}{l}0.002 * * \\
(0.001)\end{array}$ \\
\hline CPI_CHNG & & & $\begin{array}{l}-1.680 \\
(1.764)\end{array}$ & $\begin{array}{l}-0.782 \\
(1.620)\end{array}$ & & & $\begin{array}{l}-3.687 \\
(2.764)\end{array}$ \\
\hline UNEMPL & & & & $\begin{array}{l}2.468 * * * \\
(0.608)\end{array}$ & $\begin{array}{l}2.547 * * * \\
(0.754)\end{array}$ & $\begin{array}{l}3.667 \\
(2.303)\end{array}$ & $\begin{array}{l}-1.965 \\
(2.079)\end{array}$ \\
\hline INTEREST & & & & & $\begin{array}{l}-0.285 \\
(1.091)\end{array}$ & & \\
\hline CREDIT & & & & & & $\begin{array}{l}0.550 * * \\
(0.254)\end{array}$ & \\
\hline OLD_AGE & & & & & & & $\begin{array}{l}-0.472 \\
(0.998)\end{array}$ \\
\hline Wald test ( $p$ values) & 0.036 & 0.003 & 0.000 & 0.000 & 0.000 & 0.000 & 0.000 \\
\hline $\begin{array}{l}\text { Second-order correlation } \\
\quad(p \text { values })^{\mathrm{a}}\end{array}$ & 0.527 & 0.834 & 0.887 & 0.734 & 0.723 & 0.446 & - \\
\hline Hansen's J-stat ( $p$ values $)^{\mathrm{b}}$ & 0.549 & 0.618 & 0.624 & 0.553 & 0.556 & 0.707 & 0.652 \\
\hline Countries & 13 & 13 & 13 & 13 & 13 & 12 & 13 \\
\hline Observations & 169 & 169 & 169 & 169 & 169 & 72 & 26 \\
\hline
\end{tabular}

Standard errors in parentheses.

Number of instruments: regression 1 15, 2 16, 3 17, 4 18, 5 18, 617,716 .

$* * *, * *, *$ indicate significance at 1,5 and $10 \%$ level.

a The null is that there is zero second-order correlation in the error terms.

$\mathrm{b}$ The null is that the over-identifying restrictions are valid.

Finally, we have argued that insurance demand kicks in at a certain development stage and leads to larger-than-proportional insurance growth in emerging economies. Hence, it should be possible to show a weaker relationship of economic and insurance growth in advanced economies. As a cross-check, we repeat the above analysis for the sample of Western European countries. Accordingly, we calculate estimates for the pre- and the postcrisis periods. We show results for life insurance in Tables 7 and 8 while we do not show largely insignificant results for the non-life insurances.

The results are neither consistent nor robust to different specifications for Western European developed countries. This confirms previous findings about weaker economic growth and insurance relationships in developed economies. ${ }^{40}$ In the pre-crisis sample, GDP growth is significant in column 1, but the effect is much smaller than in the CEE regressions (Table 3), and it is not robust to other specifications. The level of GDP per capita has a statistically significant and negative effect in columns 2,3 and 7 but fails to have a significant effect in columns 4, 5 and 6. The unemployment rate has a significant effect but surprisingly influences non-life insurances premiums positively. Only credit

${ }^{40}$ Han et al. (2010); Arena (2008). 
Table 8 Western Europe life insurance premium growth post 2009, GMM-estimate

\begin{tabular}{|c|c|c|c|c|c|c|}
\hline Regressors & 1 & 2 & 3 & 4 & 5 & 6 \\
\hline \multicolumn{7}{|c|}{ Dependant variable: PREMLIFE_CHNG } \\
\hline PREMLIFE_CHNG $(-1)$ & $\begin{array}{l}-0.192 \\
(0.120)\end{array}$ & $\begin{array}{l}-0.216^{*} \\
(0.112)\end{array}$ & $\begin{array}{l}-0.257 * * * \\
(0.090)\end{array}$ & $\begin{array}{l}-0.257 * * * \\
(0.097)\end{array}$ & $\begin{array}{l}-0.209^{*} \\
(0.120)\end{array}$ & $\begin{array}{l}-0.167 \\
(0.137)\end{array}$ \\
\hline GDP_CHNG & $\begin{array}{l}-0.107 \\
(0.583)\end{array}$ & $\begin{array}{l}0.233 \\
(0.436)\end{array}$ & $\begin{array}{l}0.867 * * * \\
(0.208)\end{array}$ & $\begin{array}{l}0.850 * * * \\
(0.206)\end{array}$ & $\begin{array}{l}0.442 \\
(0.354)\end{array}$ & \\
\hline GDP_PC & & $\begin{array}{l}-0.001 \\
(0.001)\end{array}$ & $\begin{array}{l}-0.001 * \\
(0.001)\end{array}$ & $\begin{array}{l}-0.001 \\
(0.001)\end{array}$ & $\begin{array}{l}0.000 \\
(0.001)\end{array}$ & $\begin{array}{l}-0.001 \\
(0.001)\end{array}$ \\
\hline CPI_CHNG & & & $\begin{array}{l}-4.104 * \\
(2.128)\end{array}$ & $\begin{array}{l}-4.074 * * \\
(2.026)\end{array}$ & & \\
\hline UNEMPL & & & & $\begin{array}{l}0.155 \\
(1.192)\end{array}$ & $\begin{array}{l}0.618 \\
(1.723)\end{array}$ & $\begin{array}{l}0.662 \\
(1.437)\end{array}$ \\
\hline INTEREST & & & & & $\begin{array}{l}2.024 \\
(1.432)\end{array}$ & \\
\hline CREDIT & & & & & & $\begin{array}{l}-0.079 \\
(0.495)\end{array}$ \\
\hline Wald test ( $p$ values) & 0.023 & 0.056 & 0.000 & 0.000 & 0.012 & 0.006 \\
\hline Second-order correlation ( $p$ values $)^{\mathrm{a}}$ & 0.417 & 0.444 & 0.506 & 0.481 & 0.571 & 0.393 \\
\hline Hansen's J-stat $(p \text { values })^{\mathrm{b}}$ & 0.916 & 0.893 & 0.953 & 0.947 & 0.959 & 0.962 \\
\hline Countries & 13 & 13 & 13 & 13 & 13 & 12 \\
\hline Observations & 65 & 65 & 65 & 65 & 65 & 60 \\
\hline
\end{tabular}

Standard errors in parentheses.

Number of instruments: regression 1 21, 2 22, 3 23, 4 24, 5 24, 623.

$* * *, * *, *$ indicate significance at 1,5 and $10 \%$ level.

a The null is that there is zero second-order correlation in the error terms.

b The null is that the over-identifying restrictions are valid.

growth appears as a statistically significant and positive effect on life insurance growth in Western Europe. Regression results are similarly inconsistent for the post-crisis period (Table 8).

\section{Conclusions}

The 2008/2009 financial crisis and increasingly heterogeneous regional development patterns in its aftermath motivated us to reassess the broadly established drivers of life and non-life insurance development in Central and Eastern Europe. In this paper, a particular emphasise is given on the link between economic growth and insurance activities. In addition, we challenge the long-lasting belief in insurance catch-up in CEE by introducing new convergence indicators. Our paper investigates the life as well as the non-life insurance development between 1994 and 2014 in a panel of eight countries in CEE. We distinguish between the period before the 2008/2009 financial crisis and the post-crisis period. The results suggest that prior to the financial crisis economic growth had a statistically significant, strong and positive effect on growth of life insurance premiums. An increase in the annual real GDP growth rate of 1 percentage point leads to an average increase of life insurance premium growth of 2.7 percentage points. A lower 
unemployment rate is found to have a statistically significant, positive impact on non-life insurance premium growth; however, it is less important for the life insurance markets. We find statistically significant causal links for further enabling environment indicators. A sound monetary framework is generally vital for insurance development. Lower inflation enabled growth in life and non-life insurance between 1994 and 2008. Banking sector development coincides with expansion in the non-life private insurance business. The expansion in mortgage credit fuelled the $\mathrm{P} \& \mathrm{C}$ insurance markets. In $\mathrm{CEE}$, growth in credit was driven by foreign banks entering the underdeveloped financial services sectors and we show the significant impact it exerted on insurance development. Finally, the use of convergence indicators makes clear that in a long-term process this eventually would drive down insurance growth to levels that are nowadays prevailing in advanced economies. Most of the dependencies are neither statistically significant nor robust in a sample of Western European countries, providing counterfactual support for the insurance catch-up hypothesis.

The importance of an enabling environment (in turn driven by sound policies) becomes apparent once the period after 2009 is investigated. With regard to the life insurance sector, real GDP growth remained a significant driver of premium growth, although the magnitude of the effect decreased in the post-crisis period. The GDP effect does not appear robust for non-life insurances. In addition, we can neither identify convergence effects in the (shorter) period after 2009, nor further transition or significant policy influence on the insurance sector. It remains a puzzling insight of this paper that, while the model yields ample significant and robust results for the life and non-life insurance sectors before the great recession in 2008/09, the findings for the large non-life insurance sectors in CEE are mostly weak and non-significant for the subsequent period. Car purchase and registration picked up in several countries in the sample after 2009 and, hence, drove MTPL insurance takeout significantly, but this apparently happened independent of the GDP growth recovery that several CEE countries experienced in recent years. Homeownership and subsequent housing insurance has certainly suffered from the interruption in mortgage lending following the financial crisis. Credit sectors in large parts of the region remained suppressed hindering $\mathrm{P} \& \mathrm{C}$ insurance demand. Foreign capital inflow in the banking sector reversed. Big foreign players witnessed heavy loan write-downs (for example, Erste Bank in Romania), adverse effects from government treatment of foreign exchange loans (Hungary, Poland) and some banks completely withdrew or sold business in CEE (Bawag PSK, ÖVAG, Hypo Alpe Adria) propagating negative developments in bank lending and coinciding insurance activity. From the results we would infer that the weakened financial channel had a particularly negative influence on insurance activity. It adds a rather new notion to this stream of the literature to investigate how insurance dynamics in an emerging region were altered after the financial crisis. Our findings are in particular relevant for the European insurance industry that is exposed in the CEE region, and might also be relevant for insurance research in other emerging or developing regions.

\section{References}

Arellano, M. and Bond, S. (1991) "Some tests of specification for panel data: Monte Carlo evidence and an application to employment equations", The Review of Economic Studies 58(2): 277-297.

Arena, M. (2008) "Does insurance market activity promote economic growth? A cross-country study for industrialized and developing countries", The Journal of Risk and Insurance 75(4): 921-946. 
Bakker, B.B. and Klingen, C. (eds) (2010) How Emerging Europe Came through the 2008/09 Crisis - An Account by the Staff of the IMF"s European Department, Washington, DC: International Monetary Fund.

Beck, T., Feyen, E., Ize, A. and Moizeszowicz, F. (2008) Benchmarking Financial Development, Policy Research Working Paper 4638, Washington, DC: World Bank.

Beck, T. and Webb, I. (2003) "Economic, demographic and institutional determinants of life insurance consumption across countries", The World Bank Economic Review 17(1): 51-88.

Catalan, M., Impavido, G. and Musalem, A.R. (2000) "Contractual savings or stock market development: which leads?", Journal of Applied Social Science Studies [Schmollers Jahrbuch] 120(3): 445-487.

Ćurak, M., Lončar, S. and Poposki, K. (2009) "Insurance sector Development and Economic Growth in Transition Countries", International Research Journal on Finance and Economics 34: 29-41.

Davis, E.P. and Hu, Y.W. (2005) Is There a Link Between Pension Fund"s Assets and Economic Growth? A Cross-Country Study, Economics and Finance working paper, London: Brunel University.

Dragos, S.L. (2014) "Life and non-life insurance demand: the different effects of influence factors in emerging countries from Europe and Asia”, Economic Research - Ekonomska Istrazivanj 27(1): 169-180.

Enz, R. (2000) “The S-curve relation between per-capita income and insurance penetration”, The Geneva Papers on Risk and Insurance - Issues and Practice 25(3): 396-406.

Feyen, E., Rodney, L. and Rocha, R. (2011) What Drives the Development of the Insurance Sector? An Empirical Analysis Based on a Panel of Developed and Developing Countries, Policy Research Working Paper 5572, Washington, DC: World Bank.

Fink, G., Haiss, P. and Vukšić, G. (2009) "Contribution of financial market segments at different stages of development: transition, cohesion and mature economies compared", Journal of Financial Stability 5(4): 431-455.

Han, L., Li, D., Fariborz, M. and Yanhui, T. (2010) "Insurance development and economic growth", The Geneva Papers on Risk and Insurance - Issues and Practice 35(2): 183-199.

Hwang, T. and Greenford, B. (2005) "A cross-section analysis of the determinants of life insurance consumption in mainland China, Hong Kong and Taiwan”, Risk Management and Insurance Review 8(1): 103-125.

Impavido, G., Musalem, A. R. and Tressel, T. (2003) The Impact of Contractual Savings Institutions on Securities Markets, World Bank Policy Research Working Paper 2948, Washington, DC: World Bank.

International Monetary Fund (2015) World Economic Outlook: Adjusting to Lower Commodity Prices (October), Washington, DC: International Monetary Fund.

King, R.G. and Levine, R. (1993) "Finance and growth: Schumpeter might be right", Quarterly Journal of Economics, 108 (3): 717-737.

Kjosevski, J. (2012) "The determinants of life insurance demand in Central and Southeastern Europe", International Journal of Economics and Finance 4(3): 237-247.

Kozarevic, S., Peressin, L. and Valentinuz, G. (2013) "Efficiency of the transition of insurance markets in SouthEastern European post-Communist countries", South-Eastern Europe Journal of Economics 11(2): 139-164.

Levine, R. (1998) "The legal environment, banks and long-run economic growth", Journal of Money, Credit, and Banking 30(3): 596-613.

Levine, R. (1999) "Law, finance and economic growth", Journal of Financial Intermediation 8 (1-2): 8-35.

Levine, R. (2002) "Bank-based or market-based financial systems: which is better?", Journal of Financial Intermediation 11 (4): 398-428.

Levine, R. and Zervos, S. (1998) "Stock markets, banks and economic growth", The American Economic Review 88(3): 537-558.

Njegomir, V. and Stojić, D. (2010) "Does Insurance promote economic growth: the evidence from ex-Yugoslavia region”, Ekonomska Misao i Praksa [Economic Thought and Practice] 19(1): 31-48.

Outreville, J.-F. (1990) "The economic significance of insurance markets in developing countries", The Journal of Risk and Insurance 57(3): 487-498.

Outreville, J.F. (1992) "The relationship between insurance, financial development and market structure in developing countries: an international cross-section study", UNCTAD Review 3: 53-69.

Outreville, J.F. (1996) "Life insurance markets in developing countries", The Journal of Risk and Insurance 63(2): 263-278.

Outreville, J.F. (2011) The Relationship Between Insurance Growth and Economic Development: 80 Empirical Papers for a Review of the Literature ICER Working Paper No. 12/2011, Torino, Italy: International Centre for Economic Research.

Phutkaradze, J. (2014) "Impact of insurance market on economic growth in post-transition countries", International Journal of Management and Economics 44(1): 92-105. 
Sen, S. (2008) An Analysis of Life Insurance Demand Determinants for Selected Asian Economies and India, Working Paper 36/2008, Chennai: Madres School of Economics.

UNIQA Insurance Group AG (2013) UNIQA Group Report 2013, Vienna: UNIQA Insurance Group AG.

Ward, D. and Zurbruegg, R. (2002) "Law, politics and life insurance consumption in Asia", The Geneva Papers on Risk and Insurance - Issues and Practice 27(3): 395-412.

Webb, I., Grace, M.F. and Skipper, H.D. (2002) The Effect of Banking and Insurance on the Growth of Capital and Output, Working Paper 02-1, Atlanta, GA: Robinson College of Business, Georgia State University.

Yaari, M.E. (1964) "On the consumer"s lifetime allocation process", International Economic Review 5(3): 304-317.

Yaari, M.E. (1965) "Uncertain lifetime, life insurance and the theory of the consumer", Review of Economic Studies 32(2): 137-150.

Zheng, W., Liu, Y. and Deng, Y. (2009) “A comparative study of international insurance markets”, The Geneva Papers on Risk and Insurance - Issues and Practice 34(1): 85-99.

\section{Appendix}

Table 9 Definitions and sources of variables

\begin{tabular}{|c|c|c|}
\hline Variable & Definition & Source \\
\hline $\begin{array}{l}\text { Insurance premium growth } \\
\text { ("PREMTOT_CHNG") }\end{array}$ & $\begin{array}{l}\text { Percentage annual change in real total gross insurance } \\
\text { premiums }\end{array}$ & $\begin{array}{l}\text { Swiss Re } \\
\text { Sigma }\end{array}$ \\
\hline $\begin{array}{l}\text { Life insurance premium growth } \\
\text { ("PREMLIFE_CHNG") }\end{array}$ & $\begin{array}{l}\text { Percentage annual change in real life gross insurance } \\
\text { premiums }\end{array}$ & $\begin{array}{l}\text { Swiss Re } \\
\text { Sigma }\end{array}$ \\
\hline $\begin{array}{l}\text { Non-life insurance premium growth } \\
\text { ("PREMNONLIFE_CHNG") }\end{array}$ & $\begin{array}{l}\text { Percentage annual change in real non-life (including health) } \\
\text { gross insurance premiums }\end{array}$ & $\begin{array}{l}\text { Swiss Re } \\
\text { Sigma }\end{array}$ \\
\hline GDP growth (“GDP_CHNG”) & Percentage annual change in real GDP & $\begin{array}{r}\text { IMF WEO } \\
102015\end{array}$ \\
\hline GDP per capita ("GDP_PC") & US Dollar GDP per capita based on purchasing power parity & $\begin{array}{r}\text { IMF WEO } \\
102015\end{array}$ \\
\hline Inflation ("INFLATION") & Percentage annual change in the consumer price index & $\begin{array}{r}\text { IMF WEO } \\
102015\end{array}$ \\
\hline Unemployment Rate (“UNEMPL”) & Percent of total labour force & $\begin{array}{r}\text { IMF WEO } \\
102015\end{array}$ \\
\hline Real interest rate ("INTEREST") & $\begin{array}{l}\text { Nominal interest rate minus inflation rate. The nominal } \\
\text { interest rate is the lending rate or, if unavailable, the money } \\
\text { market rate (Poland, Slovenia) }\end{array}$ & IMF (IFS) \\
\hline Real credit growth (“CREDIT") & $\begin{array}{l}\text { Percentage annual change of claims by deposit banks and } \\
\text { other financial institutions on domestic private sector minus } \\
\text { inflation rate }\end{array}$ & IMF (IFS) \\
\hline $\begin{array}{l}\text { Real lending for house purchase } \\
\text { ("MORTGAGES") }\end{array}$ & $\begin{array}{l}\text { Percentage annual change in lending to households for house } \\
\text { purchase (all maturities, all currencies) minus inflation rate }\end{array}$ & $\mathrm{ECB}$ \\
\hline Vehicle registrations ("CARS") & Percentage annual change in vehicle registrations & ACEA \\
\hline $\begin{array}{l}\text { Other investment (financial account, } \\
\text { BoP) ("FOREIGN") }\end{array}$ & $\begin{array}{l}\text { Other investment (liabilities, financial account, balance of } \\
\text { payments) as percent of nominal GDP }\end{array}$ & IMF (IFS) \\
\hline $\begin{array}{l}\text { EBRD Transition Indicator } \\
\text { ("TRANSITION") }\end{array}$ & $\begin{array}{l}\text { Sum of EBRD Transition indicators (large scale privatisation, } \\
\text { small scale privatisation, governance and enterprise } \\
\text { restructuring, price liberalisation, trade and foreign } \\
\text { exchange system, competition policy) divided by number } \\
\text { of EBRD transition indicators }\end{array}$ & EBRD \\
\hline
\end{tabular}


Table 9 continued

\begin{tabular}{lll}
\hline Variable & Definition & Source \\
\hline $\begin{array}{l}\text { Cost of business start-up procedures } \\
\text { ("START_UP") }\end{array}$ & $\begin{array}{c}\text { Per capita cost of business start-up } \\
\text { procedures } \\
\text { Old-age dependency ratio ("OLD_AGE") }\end{array}$ & $\begin{array}{c}\text { World Bank } \\
\text { (WDI) } \\
\end{array}$ \\
\hline
\end{tabular}

\section{About the Author}

Martin Ertl is chief economist at UNIQA Capital Markets, the asset management subsidiary of UNIQA Insurance Group, Vienna, Austria.

This work is licensed under a Creative Commons Attribution 3.0 Unported

License. The images or other third party material in this article are included in the article's Creative Commons license, unless indicated otherwise in the credit line; if the material is not included under the Creative Commons license, users will need to obtain permission from the license holder to reproduce the material. To view a copy of this license, visit http://creativecommons.org/licenses/by/3.0/. 